GSA Data Repository item 2009103

\title{
Carrapa et al.
}

\section{U-Th-Pb Geochronology}

U-Pb geochronology was conducted by laser ablation multicollector inductively coupled plasma mass spectrometry (LA-MC-ICPMS) at the Arizona LaserChron Center (Gehrels et al., 2008). The analyses involve ablation of zircon with a New Wave DUV193 Excimer laser (operating at a wavelength of $193 \mathrm{~nm}$ ) using a spot diameter of 35 microns. The ablated material is carried with helium gas into the plasma source of a Micromass Isoprobe, which is equipped with a flight tube of sufficient width that $\mathrm{U}$, Th, and $\mathrm{Pb}$ isotopes are measured simultaneously. All measurements are made in static mode, using Faraday detectors with $10 \mathrm{e} 11 \mathrm{ohm}$ resistors for ${ }^{238} \mathrm{U},{ }^{232} \mathrm{Th},{ }^{208} \mathrm{~Pb}$, and ${ }^{206} \mathrm{~Pb}$, a Faraday detector with a $10 \mathrm{e} 12 \mathrm{ohm}$ resistor for ${ }^{207} \mathrm{~Pb}$, and an ion-counting channel for ${ }^{204} \mathrm{~Pb}$. Ion yields are $\sim 1 \mathrm{mv}$ per ppm. Each analysis consists of one 12 -second integration on peaks with the laser off (for backgrounds), 12 one-second integrations with the laser firing, and a 30 second delay to purge the previous sample and prepare for the next analysis. The ablation pit is $\sim 10$ microns in depth.

For each analysis, the errors in determining ${ }^{206} \mathrm{~Pb} /{ }^{238} \mathrm{U}$ and ${ }^{206} \mathrm{~Pb} /{ }^{204} \mathrm{~Pb}$ result in a measurement error in the ${ }^{206} \mathrm{~Pb} /{ }^{238} \mathrm{U}$ age of as low as $1 \%$ to as much as $10 \%$, depending on the age and $\mathrm{U}$ concentration. The errors in measurement of ${ }^{206} \mathrm{~Pb} /{ }^{207} \mathrm{~Pb}$ and ${ }^{206} \mathrm{~Pb} /{ }^{204} \mathrm{~Pb}$ are substantially larger due to low intensity of the ${ }^{207} \mathrm{~Pb}$ signal. For this reason, all ages reported are based on ${ }^{206} \mathrm{~Pb} /{ }^{238} \mathrm{U}$.

Common $\mathrm{Pb}$ correction is accomplished by using the measured ${ }^{204} \mathrm{~Pb}$ and assuming an initial Pb composition from Stacey and Kramers (1975) (with uncertainties of 1.0 for ${ }^{206} \mathrm{~Pb} /{ }^{204} \mathrm{~Pb}$ and 0.3 for ${ }^{207} \mathrm{~Pb} /{ }^{204} \mathrm{~Pb}$ ). Our measurement of ${ }^{204} \mathrm{~Pb}$ is unaffected by 
the presence of ${ }^{204} \mathrm{Hg}$ because backgrounds are measured on peaks (thereby subtracting any background ${ }^{204} \mathrm{Hg}$ and ${ }^{204} \mathrm{~Pb}$ ), and because very little $\mathrm{Hg}$ is present in the argon gas.

Because a well-calibrated standard for apatite does not yet exist, inter-element fractionation of $\mathrm{Pb} / \mathrm{U}$ was constrained by analysis of Bear Lake Road titanite (age $=1050$ \pm 1 Ma: J. Aleinikoff and M. Schmitz, written communication), a Sri Lanka zircon crystal (age $=563.5 \pm 3.2$ Ma: Gehrels et al., 2008), and NIST SRM 610 trace element glass $\left({ }^{206} \mathrm{~Pb} /{ }^{238} \mathrm{U}=0.2565\right.$ : Stern and Amelin, 2003). Bear Lake Road titanite was used as the primary standard, and yielded a fractionation-corrected age of $1050 \pm 10$ Ma (2-sigma). Nine Sri Lanka zircon analyses yielded an average age of $553 \pm 9$ Ma, which is $1.9 \%$ younger than the known age. The two analyses of NIST SRM 610 yielded ${ }^{206} \mathrm{~Pb} /{ }^{238} \mathrm{U}$ ratios of 0.2507 and 0.2518 , which are $2.3 \%$ and $1.8 \%$ lower than the known ratio. Collectively, these analyses indicate that our ${ }^{206} \mathrm{~Pb} /{ }^{238} \mathrm{U}$ ages of unknown apatites are accurate to within 2-3\%. The analytical data are reported in Table DR1. Uncertainties shown in these tables are at the 1-sigma level, and include only measurement errors. Inclusion of all systematic errors would add an additional 3\% to each analysis.

\section{${ }^{40} \mathrm{Ar} /{ }^{39} \mathrm{Ar}$ thermochronology}

The ${ }^{40} \mathrm{Ar} /{ }^{39} \mathrm{Ar}$ dating has been performed at the ${ }^{40} \mathrm{Ar} /{ }^{39} \mathrm{Ar}$ geochronology laboratory in the University of Potsdam. Neutron activation of samples by the fast neutron and Ar isotopic analysis have been processed as follows. Neutron activation of the samples has been performed at Geesthacht Neutron Facility (GeNF), GKSS, Germany. The prepared unknown samples have been wrapped by the commercial $\mathrm{Al}$ foils then contained in the 99.999\% pure Al sample holder, which has a column shape with $20 \mathrm{~mm}$ diameter and 60 
mm height. The sample holder consists of stacked twelve Al disks containing unknown samples in the drilled holes of each disk including the bottom and top disks. The sample holder is finally wrapped in a $0.5 \mathrm{~mm}$ thick Cd foil in order to eliminate the unnecessary thermal neutron flux that produces interfering Ar isotopes, (e.g. by the reaction of ${ }^{40} \mathrm{~K}(\mathrm{n}$, p) ${ }^{40} \mathrm{Ar}$ ). The fast neutron flux used for the irradiation at the relatively peripheral position in the reactor is about $1 \times 10^{12} \mathrm{n} / \mathrm{cm}^{2} / \mathrm{s}$. For this study, up to 100 grains with roughly 300 micron of diameter per prepared white mica sample had been irradiated in March, 2006, for 4 days (96 hours) to produce enough amount of ${ }^{39} \mathrm{Ar}$ by the reaction of ${ }^{39} \mathrm{~K}(\mathrm{n}, \mathrm{p}){ }^{39} \mathrm{Ar}$ with the fast neutron flux. Fish Canyon Tuff sanidine has been irradiated together with the unknown samples as a neutron flux-monitoring mineral standard to obtain $\mathrm{J}$ values, which are the parameters that indicate the degree of neutron activation in the irradiated samples. The standard Fish Canyon Tuff sanidine had been prepared at the Geological Survey of Japan and the age had been determined as 27.5 Ma (Uto et al., 1997; Ishizuka et al., 2002). The crystals of $\mathrm{K}_{2} \mathrm{SO}_{4}$ and $\mathrm{CaF}_{2}$ have also been irradiated together with the samples in order to correct the interference of Ar isotopes produced by the reactions of the neutron fluxes with $\mathrm{K}$ or $\mathrm{Ca}$ in the samples.

After one month for cooling down of the activities of the irradiated samples, the $\mathrm{Ar}$ isotopic analyses have been performed in January, 2007, at the ${ }^{40} \mathrm{Ar} /{ }^{39} \mathrm{Ar}$ geochronology laboratory at the University of Potsdam (Institute of Earth Sciences). The Ar isotopic analytical system used in this study consists of, (1) a New Wave Gantry Dual Wave laser ablation system with a $50 \mathrm{~W} \mathrm{CO}_{2}$ laser (wavelength 10.6 micrometer) for heating and extracting gas from samples, (2) an ultra-high vacuum purification line with SAES getters, and (3) a Micromass 5400 magnetic sector-type noble gas mass spectrometer 
with a high sensitivity and a ultra-low background. The mass spectrometer has adopted a pulse counting system with an electron multiplier which effectively works for the very small amounts of gas like our case.

The total fusion or the single stepwise heating of white muscovite grains have been conducted with a defocused continuous $\mathrm{CO}_{2}$ laser beam with a similar beam diameter to the samples for 1 minute. Then, the extracted gas has been exposed to SAES getters (and a cold trap for 10 minutes to purify the sample gas to pure Ar gas. Finally the Ar gas has been introduced to the mass spectrometer to determine the Ar isotopic ratios. The isotopic ratios of each analysis have finally been obtained after corrections of blank, mass discrimination by the analysis of atmospheric argon, interference of Ar isotopes derived from $\mathrm{Ca}$ and $\mathrm{K}$, and the decay of the Ar isotopes $\left({ }^{37} \mathrm{Ar}\right.$ and $\left.{ }^{39} \mathrm{Ar}\right)$ produced by the irradiation. The calculation of the ages and errors has followed Uto et al. (1997).

Obtained $\mathrm{J}$ values range between $1.768 \times 10^{-3}$ and $1.691 \times 10^{-3}$ through the irradiation capsule. The error of the $\mathrm{J}$ value has been estimated as $0.4 \%$ from the results obtained by recent three sets of irradiations. The spatial distribution of the $\mathrm{J}$ values shows similar tendencies to the results obtained by the GEOMAR group (Bogaard, 1995) using the same GeNF reactor. Obtained parameters used for the correction of the interference by $\mathrm{Ca}$ and $\mathrm{K}$ in this study are as follows: $\left({ }^{39} \mathrm{Ar} /{ }^{37} \mathrm{Ar}\right)_{\mathrm{Ca}}:(9.177 \pm 0.148) \times 10^{-4},\left({ }^{36} \mathrm{Ar} /{ }^{37} \mathrm{Ar}\right)_{\mathrm{Ca}}$ : $(4.382 \pm 0.016) \times 10^{-4},\left({ }^{40} \mathrm{Ar} /{ }^{39} \mathrm{Ar}\right)_{\mathrm{K}}:(48.8 \pm 8.3) \times 10^{-4},\left({ }^{38} \mathrm{Ar} /{ }^{39} \mathrm{Ar}\right)_{\mathrm{K}}:(1.839 \pm 0.025) \times 10^{-2}$.

\section{Apatite Fission Track thermochronology}

Apatite Fission Track thermochronology provides information on the timing and rates of cooling occurring at temperature $(\mathrm{T})$ between ca. $60-120^{\circ} \mathrm{C}$, defined as the Partial 
Annealing Zone (PAZ). The exact $\mathrm{T}$ of the upper (hotter) boundary depends on the kinetic characteristics of the apatites and the cooling rate; the former can be quantified by measuring the diameter of track etch pits, known as Dpar (Donelick et al., 1999; Gallagher et al., 1998; Ketcham et al., 1999). In general, smaller $\mathrm{D}_{\text {par }}$ are typical of flourine-rich apatites and are characterized by lower temperatures of the upper boundary. Fission track-lengths provide information on the proportion of the cooling history that the sample experienced within the PAZ, and hence how quickly the apatite passed through the PAZ. Therefore, in order to interpret the AFT data in terms of a T-t path an integrated analysis of fission-track age, track length distribution, and kinetic characteristics of the apatite grains $\left(\mathrm{D}_{\text {par }}\right)$ is necessary. Samples were prepared and analyzed following the procedure described by Sobel and Strecker (2003).

An average of twenty grains for each cobble was analyzed for three samples (Table DR2 in data repository). Confined track-lengths, angle between the confined track and the C-crystallographic axis (C-axis projected data), and $\mathrm{D}_{\text {par }}$ were measured. Use of the angular data mitigates track-measurement bias (Barbarand et al., 2003) and improves annealing model results, as confined tracks anneal anisotropically as a function of orientation (Donelick et al., 1999; Ketcham et al., 1999). All samples pass the $\chi^{2}$ test (Galbraith and Green, 1990; Green, 1981); therefore, pooled ages, calculated using the Trackkey program (Dunkl, 2002), are reported in Table DR2.

\section{(U-Th)/He Thermochronometry}

Apatite He ages were analyzed at the University of Arizona. Grains were handpicked from prepared mineral concentrates with a high-power (160x) stereozoom 
microscope with cross-polarization for screening inclusions. Individual crystals selected for analysis were digitally photographed and measured in at least 2 different orientations for alpha-ejection correction. Crystals were loaded into $0.8-\mathrm{mm} \mathrm{Nb}$ foil tubes, which were loaded into stainless steel planchets and heated with a Nd-YAG laser for 3 minutes at $1-5 \mathrm{~W} .{ }^{4} \mathrm{He}$ blanks $\left(0.05-0.1 \mathrm{fmol}{ }^{4} \mathrm{He}\right)$ were determined by heating empty foil packets using the same procedure. Gas liberated from samples was processed by: 1) spiking with $\sim 4$ pmol of ${ }^{3} \mathrm{He}, 2$ ) cryogenic concentration at $16 \mathrm{~K}$ on a charcoal trap, and purification by release at $37 \mathrm{~K}$, and 3) measurement of ${ }^{4} \mathrm{He} /{ }^{3} \mathrm{He}$ ratios (corrected for $\mathrm{HD}$ and $\mathrm{H}_{3}$ by monitoring $\mathrm{H}^{+}$) on a quadruple mass spectrometer. All ratios were referenced to multiple same-day measured ratios and known volumes of ${ }^{4} \mathrm{He}$ standards processed in the same way. After degassing, samples were retrieved from the laser cell, spiked with calibrated ${ }^{229} \mathrm{Th},{ }^{233} \mathrm{U}$, and ${ }^{147} \mathrm{Sm}$ solution, and dissolved in-situ from $\mathrm{Nb}$ tubes in $\sim 30 \% \mathrm{HNO}_{3}$ in teflon vials. Each batch of samples was prepared with a series of acid blanks and spiked normals to check the purity and calibration of the reagents and spikes. Spiked solutions were analyzed as $0.5 \mathrm{~mL}$ of $\sim 1.5 \mathrm{ppb}$ U-Th solutions by isotope dilution on a Thermo Element2 ICP-MS. For whole, unpolished grains, alpha-ejection was corrected using the method of Farley (2000). For polished grains with euhedral to subhedral morphologies plucked from AFT mounts, the method of Reiners et al. (2007) was used for alphaejection correction. Polished anhedral grains with no identifiable original crystal faces were not corrected for alpha ejection.

\section{Thermal modelling}

Thermal modeling was conducted using HeFTy program (version 1.5.6) (Ketcham, 2005). For all samples the model was initiated at a time (t) corresponding to at 
least double the fission track pooled age of the considered sample. A T between $5-20^{\circ} \mathrm{C}$ was considered as present-day surface $\mathrm{T}$; no extra additional t-T constrains were initially used. AFT data were modeled using the Ketcahm et a. (1999) annealing model together with (U-Th)/He data that were modeled using the Shuster et al. (2006) and the Farley et al. (1996) method for calibration alpha ejection correction.

For sample TG 41 the (U-Th)/He age of $52.8 \pm 3.21$ was used for modeling. The only acceptable fits were obtained when the following constraints were applied: exhumation between ca. 55 and 25 Ma and burial between ca. 35 and 8 Ma. For sample TG 408 the best results were obtained when the following constraints were applied: exhumation between ca. 55 and 25 Ma and burial between ca. 38 and 15 Ma.

Apatite fission track Population P2 from sample 2SP38 from the Geste Formation was selected and modeled together with the youngest (U-Th)/He age (8.02 $\pm 0.28 \mathrm{Ma})$ in order to check on late Tertiary basin incision. The only acceptable solutions were obtained with the following inputs: source exhumation between 56 - 35 Ma, burial between ca. 48 and 10 Ma and basin exhumation between 12 and 0 Ma. All the applied constraints are supported by geological evidence (Carrapa and DeCelles, 2008).

\section{References}

Barbarand, J., Hurford, A.J., and CArter, A., 2003, Variation in apatite fission-track length measurement: implications for thermal history modeling: Chemical geology, v. 198, p. 77-106.

Donelick, R.A., Ketchman, R.A., and Carlson, W.D., 1999, Variability of apatite fission track annealing kinetics: II. Crystallographic orientation effects: American Mineralogist, v. 84, p. 1224-1234. 
Dumitru, T.A., 1993, A new computer automated microscope stage system for fission track analysis: Nuclear tracks and radiation measurements, v. 21, p. 575-580.

Dunkl, I., Trackkey, windows program for calculation and graphical presentation of EDM fission track data, $\quad$ version $\quad$ 4.2: http://www.sediment.unigoettingen.de/staff/dunkl/software/trackkey.html, 2002.

Farley, K.A., 2000, (U-Th)/He Dating: Techniques, Calibrations, and Applications, Reviews in Mineralogy and Geochemistry v. 47, p. 819-844.

Farley, K., Wolf, R.A., Silver, L.T., 1996, The effects of long-alpha stopping distances on (UTh)/He ages. Goehcem. Cosmochem. Acta, v.60, p.4223-4229.

Galbraith, R.F., and Green, P.F., 1990, Estimating the component ages in a finite mixture: Nuclear tracks and radiation measurements, v. 17, p. 197-206.

Gallagher, K., Brown, R., and Johnson, C., 1998, Fission track analysis and its applications to geological problems: Annual Review of Earth and Planetary Sciences, v. 26, p. 519-572.

Gehrels, G., Valencia, V., Ruiz, J., 2008, Enhanced precision, accuracy, efficiency, and spatial resolution of U-Pb ages by LA-MC-ICPMS: Geochemistry, Geophysics, Geosystems: v. 9, Q03017, doi:10.1029/2007GC001805.

Green, P.F., 1981, A new look at statistics in fission-track dating: Nuclear tracks and radiation measurements, v. 5, p. 77-86.

Hurford, A.J., and Green, P.F., 1983, The zeta age calibration of fission-track dating: Chemical geology, v. 41, p. 285-317.

Ishizuka, O., M. Yuasa and K. Uto (2002): Evidence of porphyry copper-type hydrothermal activity from a submerged remnant back-arc volcano of the Izu-Bonin arc: Implication for the volcanotectonic history of back-arc seamounts. Earth and Planetary Science Letters, 198, 381-399.

Ludwig, K.R., 2003, Isoplot 3.00. Berkeley Geochronology Center, Special Publication 4, 70 p. 
Ketcham, R.A., 2005, Forward and inverse modeling of low-temperature thermochronometry data: Mineral. Soc. Am. Rev. Mineral. Geochem, v. 58, p. 275-314.

Ketcham, R.A., Donelick, R.A., and Carlson, W.D., 1999, Variability of apatite fission-track annealing kinetics: III. Extrapolation to geological time scales: American Mineralogist, v. 84 , p. $1235-1255$.

Ketcham, R.A., 2005, Forward and inverse modeling of low-temperature thermochronometry data. Rev. Mineral Geochem., v.58, p. 275-314.

Reiners, P.W., Thomson, S.N., McPhillips, D., Donelick, R.A., and Roering, J.J., 2007, Wildfire thermochronology and the fate and transport of apatite in hillslope and fluvial environments, Journal of Geophysical Research-Earth Surface, v. 112, F04001, doi:10.1029/2007JF000759.

Shuster, D.L., Flower, R.M., Farley, K.A., 2006, The influence of natural radiation damage on helium diffusion kinetics in apatite. Earth and Planetary Science Letters, v. 249, p. 148161.

Sobel, E., and Strecker, M.R., 2003, Uplift, exhumation and precipitation: tectonic and climatic control of Late Cenozoic landscape evolution in the northern Sierras Pampeanas, Argentina: Basin Research, v. 15, p. 431-451.

Stacey, J.S., and Kramers, J.D., 1975, Approximation of terrestrial lead isotope evolution by a two-stage model: Earth and Planetary Science Letters, v. 26, p. 207-221.

Stern, R., Amelion, Y., 2003, Assessment of errors in SIMS zircon U-Pb geochronology using a natural zircon standard and NIST SRM 610 glass: Chemical Geology, v. 197, p. 111-142.

Uto, K., O. Ishizuka, A. Matsumoto, H. Kamioka and S. Togashi (1997): Laser-heating ${ }^{40} \mathrm{Ar} /{ }^{39} \mathrm{Ar}$ dating system of the Geological Survey of Japan: System outline and preliminary results. Bulletin of the Geological Survey of Japan, 48, 23-46. 
van den Bogaard, P. (1995): ${ }^{40} \mathrm{Ar} /{ }^{39} \mathrm{Ar}$ ages of sanidine phenocrysts from Laacher See Tephra (12,900 yr BP): Choronostratigraphic and petrological significance. Earth and Planetary Science Letters, 133, 163-174. 


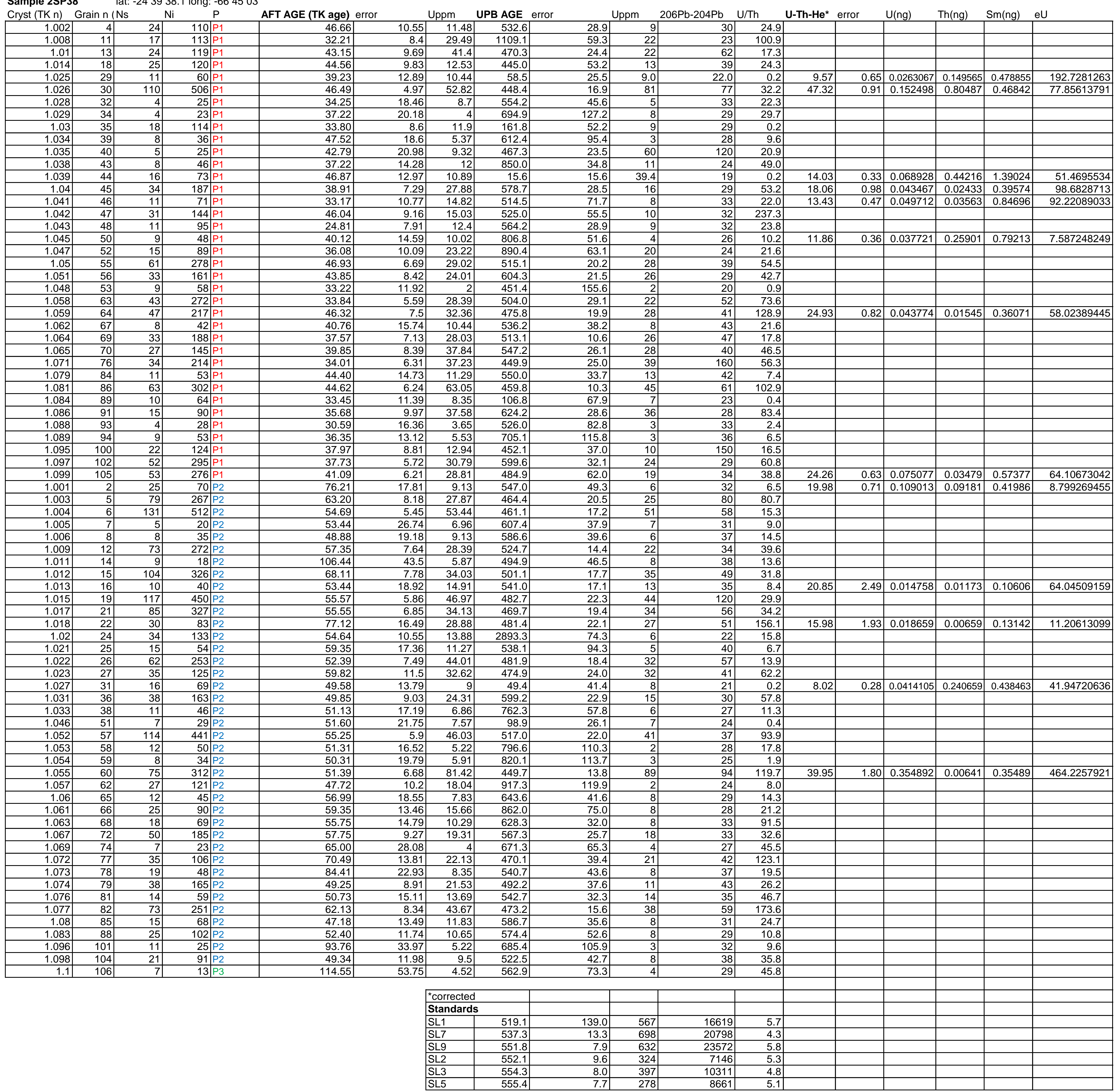




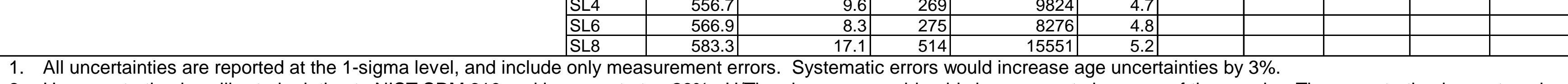
2. U concentration is calibrated relative to NIST SRM 610 and is accurate to $20 \%$. U/T values are considerably less accurate because of the very low Th concentration in most analyses.

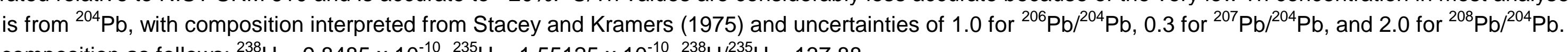
4. U decay constants and composition as follows: ${ }^{238} \mathrm{U}=9.8485 \times 10^{-10},{ }^{235} \mathrm{U}=1.55125 \times 10^{-10},{ }^{238} \mathrm{U} / \mathrm{C}^{235} \mathrm{U}=137.88$
*different from the sequential number in the TK file (Carrapa and DeCelles, 2008) 


\begin{tabular}{|c|c|c|c|c|c|c|c|c|c|c|c|c|c|}
\hline Sample name & $\begin{array}{c}\text { raw age } \\
(\mathrm{Ma})\end{array}$ & $\begin{array}{l} \pm 1 \sigma \\
\text { (Ma) }\end{array}$ & $\begin{array}{c}\text { err on raw } \\
\%\end{array}$ & $\begin{array}{c}\text { mass } \\
(\mathrm{ng})\end{array}$ & $\begin{array}{r}\text { mwar } \\
(\mu \mathrm{m})\end{array}$ & $\mathrm{eUU}$ & $\begin{array}{l}\text { Th } \\
\text { ng }\end{array}$ & $\begin{array}{c}\text { Sm } \\
n g\end{array}$ & $\begin{array}{l}{ }^{4} \mathrm{He} \\
(\mathrm{nmol} / \mathrm{g})\end{array}$ & $\begin{array}{c}\text { corrected age } \\
\text { (Ma) }\end{array}$ & $\begin{array}{l} \pm 1 \sigma \\
(\mathrm{Ma})\end{array}$ & lat & long \\
\hline$\overline{\text { TG41aA }}$ & 32.6 & 2.93 & 9.0 & 0.74 & 34 & 15 & 0.019 & 0.264 & 2.67 & 55.0 & 4.95 & -24.557 & -67.319 \\
\hline TG41aB & 32.8 & 2.00 & 6.1 & 1.02 & 36 & 15 & 0.026 & 0.399 & 2.68 & 52.8 & 3.21 & & \\
\hline TG190aA & 25.9 & 1.51 & 5.8 & 0.83 & 29 & 26 & 0.035 & 0.293 & 3.70 & 47.5 & 2.76 & & \\
\hline TG408aA & 19.2 & 1.66 & 8.7 & 1.78 & 40 & 9 & 0.021 & 0.566 & 0.961 & 29.6 & 2.56 & & \\
\hline TG408aB & 29.6 & 1.58 & 5.4 & 1.06 & 33 & 20 & 0.027 & 0.650 & 3.25 & 50.1 & 2.68 & & \\
\hline \multicolumn{14}{|c|}{ Fission Track data* } \\
\hline \multirow[t]{2}{*}{ 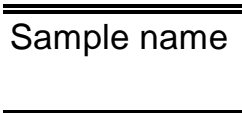 } & Rho-S & NS & Rho-I & $\mathrm{NI}$ & $\mathrm{P}(x)^{2}$ & Rho-D & ND & Age & $\pm 1 \sigma$ & $\mathrm{U}$ & mean length* & $\overline{\overline{D p r}}$ & \\
\hline & (e5)† & & $\times 105$ & & (\%) \# & $\times 105$ & & (Ma) & $\mathrm{Ma}$ & $\mathrm{ppm}$ & $\mu \mathrm{m}$ & $\mu \mathrm{m}$ & \\
\hline$\overline{T G} 41$ & 5.45 & 499 & 5.177 & 474 & 81.15 & 5.5982 & 3686 & 107.6 & 7.6 & 12.04 & $13.1 \pm 1.1$ & 1.45 & \\
\hline TG190 & 6.436 & 514 & 5.923 & 514 & 59.79 & 5.523 & 3686 & 109.5 & 7.7 & 13.54 & NA & NA & \\
\hline TG408 & 2.481 & 237 & 5.37 & 513 & 31.37 & 5.4478 & 3686 & 46.2 & 3.9 & 11.91 & $13 \pm 1.5$ & 1.4 & \\
\hline
\end{tabular}

*Samples were analyzed with an Olympus BH2 microscope (at UW) with drawing tube located above a digitizing tablet and a Kinetek computer-controlled stage driven by the FTStage program [Dumitru, 1993]. Analysis is performed with reflected and transmitted light at $1875 \mathrm{X}$ magnification. Samples were irradiated at Washington State University. Samples were etched in 5.5 molar nitric acid at $21 \pm{ }^{\circ} \mathrm{C}$ for $20 \mathrm{~s}$. Following irradiation, the mica external detectors were etched with $21 \pm^{\circ} \mathrm{C}, 40 \%$ hydrofluoric acid for $45 \mathrm{~min}$. The pooled age is reported for all samples as they pass the $\chi^{2}$ test. Error is one $\sigma$, calculated using the zeta calibration method [Hurford and Green, 1983] with zeta of $368.2 \pm 9.2$ for apatite (B. Carrapa). Dpar, fission track etch pit measurements.

Rho-S and Rho-I are the spontaneous and induced track density measured, respectively (tracks/cm2).

$\mathrm{NS}$ and $\mathrm{NI}$ are the number of spontaneous and induced tracks counted, respectively.

$\mathrm{P}(\chi) 2$ probability is calculated following Galbraith [1981] and Green [1981]. Values greater than 5\% are considered to pass this test and represent a single population of ages.

Rho-D is the induced track density in external detector adjacent to CN5 dosimetry glass (tracks/cm2).

$\mathrm{ND}$ is the number of tracks counted in determining Rho-D

${ }^{* *}$ lengths are here reported as c-axis corrected values for comparison with model data (Figure 3). 
Table DR3

Step heating analyses

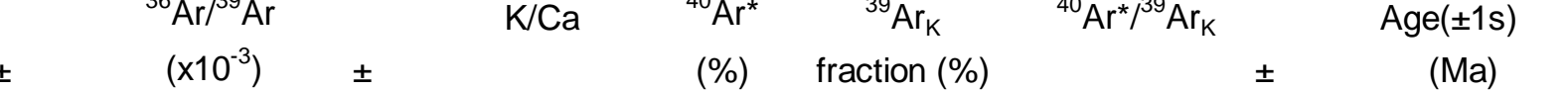

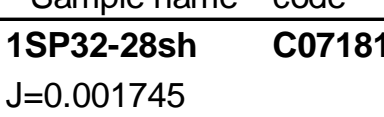

$\begin{array}{llll} & \end{array}$

$\begin{array}{llllllll}0.8 & (1276.6) & (10728) & (1392.9) & (12391) & (2155.3) & (19619.7) & (0.001) \\ 1.0 & (110.8) & (164.1) & (312.0) & (890.9) & (482.6) & (1696.6) & (0.002)\end{array}$

fusion

The values are in parentheses in the case where minus values are calculated.

Plateau age (Steps 3 - 6) : $\quad 393.8 \quad 1.0$

\begin{tabular}{|c|c|c|c|c|c|c|c|c|c|c|c|c|c|}
\hline \multicolumn{3}{|c|}{ Samole name code ${ }^{\text {"NA }{ }^{N} \mathrm{Ar}}$} & \multicolumn{2}{|c|}{ 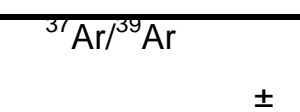 } & \multicolumn{2}{|c|}{ 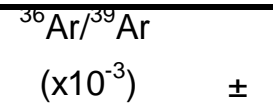 } & \multirow[t]{2}{*}{$\overline{\mathrm{K} / \mathrm{Ca}}$} & \multicolumn{2}{|c|}{ 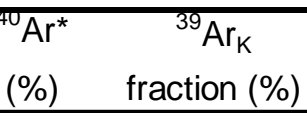 } & \multicolumn{2}{|c|}{ 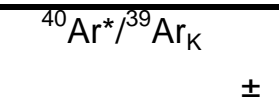 } & \multicolumn{2}{|c|}{ 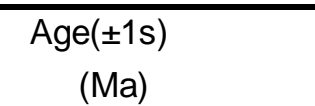 } \\
\hline 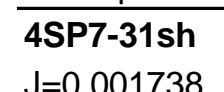 & $\begin{array}{c}07171 \\
\end{array}$ & & & & & & & & & & & & \\
\hline 0.6 & $(7.4)$ & (2.0) & 26.01 & 17.17 & 3.0 & 32.3 & 0.022 & (12.8) & 0.3 & 1.0 & 10.0 & 3.1 & (352.4 \\
\hline 0.8 & 69.0 & 45.7 & $(156.32)$ & (276.76 & (248.8) & $(600.11$ & $(0.004)$ & 177.2 & 0.0 & 1006.9 & 165.5 & 307.5 & 313.5 \\
\hline $\begin{array}{l}1-1.2 \\
1-1.2\end{array}$ & $\begin{array}{c}93.8 \\
144.5\end{array}$ & 1.7 & 3.16 & 3.08 & 78.8 & 7.5 & $\begin{array}{l}0.186 \\
3201\end{array}$ & $\begin{array}{l}75.6 \\
093 .\end{array}$ & $\begin{array}{r}1.5 \\
148\end{array}$ & $\begin{array}{l}71.1 \\
1435\end{array}$ & 2.6 & $\begin{array}{l}210.2 \\
20\end{array}$ & 7.6 \\
\hline $\begin{array}{l}-1.2 \\
1.4\end{array}$ & $\begin{array}{l}14.5 \\
141.2\end{array}$ & $\begin{array}{l}0.6 \\
0.2\end{array}$ & $\begin{array}{l}0.18 \\
0.03\end{array}$ & $\begin{array}{l}0.40 \\
0.08\end{array}$ & $\begin{array}{l}3.3 \\
0.3\end{array}$ & 0.1 & $\begin{array}{r}3.291 \\
23.062\end{array}$ & $\begin{array}{l}99.3 \\
99.9\end{array}-9$ & $\begin{array}{l}14.8 \\
75.9\end{array}$ & $\begin{array}{l}143.5 \\
141.1\end{array}$ & $\begin{array}{l}0.6 \\
0.2\end{array}-2$ & $\begin{array}{l}40.18 \\
395.6\end{array}$ & $\begin{array}{l}1.7 \\
0.5\end{array}$ \\
\hline 1.6 & 143.7 & 0.9 & 0.64 & 1.69 & 3.9 & 5.0 & 0.919 & 99.2 & 3.0 & 142.7 & 1.7 & 399.6 & 4.9 \\
\hline 1.8 & 148.6 & 7.8 & 4.19 & 14.05 & 27.7 & 13.6 & 0.140 & 94.9 & 0.5 & $\begin{array}{l}141.5 \\
1510\end{array}$ & 8.9 & 396.6 & $\begin{array}{l}24.8 \\
5.2\end{array}$ \\
\hline & & & & & & & & & & & & & \\
\hline
\end{tabular}

The values are in parentheses in the case where minus values are calculated.

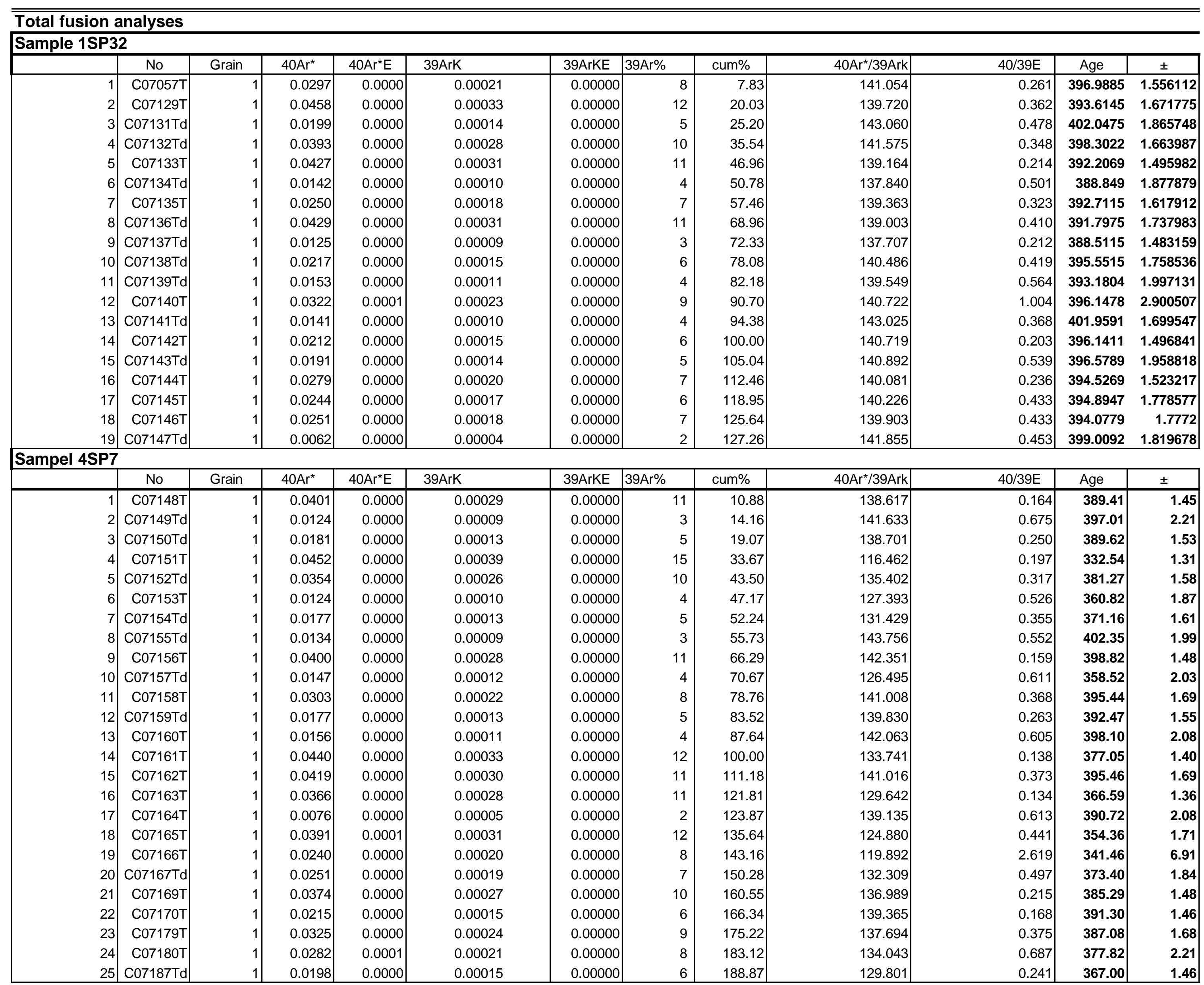

